\title{
Percy Grainger and the Early Collecting of Polynesian Music
}

GRAHAM BARWELL

University of Wollongong

\section{Introduction}

My interest in the Australian musician and composer, Percy Grainger, and his connections with the early collecting of Polynesian music, began when I visited the Australian National Portrait Gallery in Canberra. I saw there a portrait of Grainger painted in oils in 1941 by Ella Ström, Grainger's wife. ${ }^{1}$ The three-quarter length portrait shows Grainger dressed in a short bolero-style jacket of towel-like material with elbow-length sleeves over a blue shirt, and what appears to be a skirt of khaki fabric at the waist and towel material below in a pattern of brown and white reminiscent of Maori design. Grainger faces the viewer with his right hand resting on the edge of a piece of furniture, and his left hand on his hip. In the upper left is a Maori carving, possibly a figure from the gable of a house, or a post top, signalling the inspiration for his clothing. ${ }^{2}$ His pose and the portrait title, Laird of Art, point back to eighteenth- and nineteenth-century portraits of landed gentry.

As a New Zealander living in Australia, I was intrigued by the clear signals in the portrait of an interest in Maori arts, but was unaware at that time of the nature and extent of

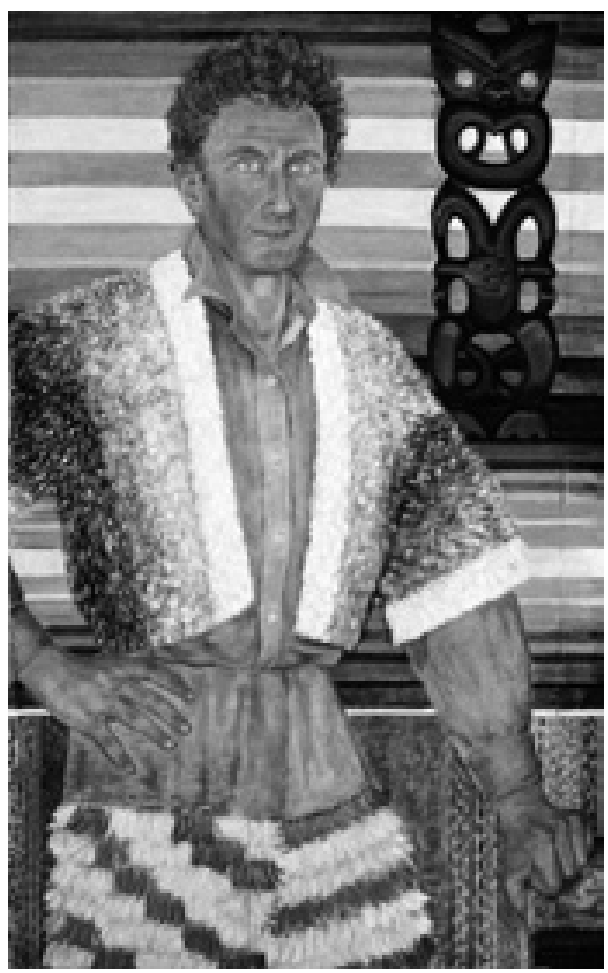


Grainger's engagement with the peoples and cultures of the Pacific. In fact, his lifelong passionate enthusiasm for the region, especially its arts, crafts and languages, formed part of his characteristic universalist impulses seen, for instance, in his championing of what is known today as 'world music' and his attraction to a wide variety of non-western cultures. Apart from an interest in the music and singing of the Pacific, he was drawn to other cultural forms - dance, beadwork, clothing, language and ritual - seeking them out whenever opportunity arose and treating them with the seriousness of a scholar and the passion of a collector. ${ }^{3}$ The extent of his interests in the region was demonstrated by an exhibition, 'Percy Grainger and the Arts of the Pacific', held in 1979 at the museum bearing his name which he had helped establish on the campus of the University of Melbourne. ${ }^{4}$

Grainger was born in 1882 and raised in Melbourne, being taken in his later teens to Germany for advanced musical training once his prodigious talents as a pianist and composer were recognised. As his biographers point out, ${ }^{5}$ Grainger's interest in the indigenous culture of New Zealand had been stimulated in late nineteenth-century Melbourne by the painter A.E. Aldis, who had spent time in that country and knew something of Maori culture, including the words and actions of songs and dances. An incurable romantic, Grainger was as deeply impressed in his boyhood by the vigour of that culture, as mediated through Aldis, as he was by the other culture which was hugely important to him throughout his life, that of Northern Europe, particularly as recorded in medieval Icelandic sagas.

It was not until he had finished his musical training and had begun a career as a professional performer that Grainger was able to have a sustained first-hand encounter with the Polynesian culture of the Pacific, joining a touring party accompanying the singer Ada Crossley for a series of performances throughout New Zealand and Australia in the early part of 1909. He had been in New Zealand for a brief concert tour in 1903 but it was the longer 1909 visit, when he was in his mid-twenties, which was the more significant. This paper will concentrate on the activities, apart from his piano recitals, which he undertook during the New Zealand leg of this tour. It will focus particularly on his relatively little known efforts to foster and promote the collection of indigenous music. ${ }^{6}$

\section{The New Zealand Leg of the Tour}

By the time Grainger joined the touring party, he had not only been through a rigorous classical musical training in the European tradition, but had also shown an active interest in folk song and folk music, a form then considered by many educated people as unworthy of professional attention. Indeed, he was already an experienced and expert collector of folk music, having begun the serious collection and arrangement of English folk music in 1905. 
Over the following five years, in the view of one of his biographers, he had achieved recognition as 'the most important folk-song collector of his day'? The significance and boldness of his approach lay in his scientific rather than nostalgic interest, and his willingness to take the music on its own terms rather than view it through the perspective and yardstick of Western European 'art music'. This was to be further demonstrated in his response to the music and song of the Pacific region. Grainger was always interested in technological developments, devising later in his career a number of ingenious devices for his Free Music experiments. In these early years he pioneered the use of the phonograph for the collection of folk song in Britain and Ireland, publishing a major article on the subject in $1908 .^{8} \mathrm{He}$ used a standard Edison-Bell phonograph, the kind of recording machine most familiar nowadays from the well-known twentieth-century trademark of the little dog, Nipper, looking into the horn from which his master's voice is issuing. ${ }^{9}$ The horn acted as both speaker and microphone for the sounds, which were recorded on wax cylinders. Grainger noted that in the field these cylinders could hold about two and a quarter minutes of recorded sound..$^{10}$

Prior to beginning the 1909 concert tour, Grainger made arrangements which indicate that he intended to use the two-month New Zealand leg to seek as much exposure as possible to Maori culture, and especially to Maori music and song. These intentions are revealed in Grainger's correspondence, published and unpublished; like many people of his day, he was a prolific correspondent by modern standards. He carried with him to New Zealand letters of introduction to a number of leading figures. For example, there are three surviving letters from P.J. Nolan, the editor of a major Sydney newspaper, The Daily Telegraph, addressed to the editors of two New Zealand newspapers, The Press and The Dominion, and to the Native Minister, the Hon. James Carroll. Each letter is much the same in format, asking the individual addressed to assist Grainger's proposed investigation of Maori 'songs' by helping him to see 'people who will give him information on the subject'." They draw attention to his collecting work in England and his contributions to the work of the Folk Song Society. Nolan, the writer of the letters, could well have been a New Zealander himself, for, in his letter to Carroll he sends regards from all the New Zealand 'boys', as he calls them, on the Telegraph. At the start of the tour Grainger told his Danish girlfriend, Karen Holten, that he had letters to leading men in native matters and to leading Maori figures, including Maui, later Sir Maui, Pomare. ${ }^{12}$

The touring party began their concerts in Invercargill on New Year's Day, then made their way north, performing in all the major and smaller towns over the course of the month, reaching Auckland at the end of January. The New Zealand performances were scheduled to finish there, to be 
followed by a week's rest at Rotorua for the touring party, but the response to the concerts was so positive that the promoters organised a series of repeat concerts, members of the party making their way southwards again, concluding in Invercargill in early March. In Dunedin, near the beginning of the tour, Grainger had received a telegram from James M. Mason, then New Zealand's first chief health officer in the Department of Public Health and, according to Grainger, 'interested in Maori songs'. ${ }^{13}$ The telegram informed Grainger that another leading Maori and potential informant, Peter, later Sir Peter, Buck, was on leave in Dunedin and Mason would wire him to contact Grainger. Buck, also known by his Maori name, Te Rangi Hiroa, then a doctor working the field of Maori health, was to go on to become one of the leading figures in Maori culture, finishing his career as Director of the Bishop Museum, Honolulu, and holder of a chair in anthropology at Yale University. As it turned out, Grainger did not meet up with Buck in Dunedin but he succeeded in doing so later in the tour. It was to be a significant meeting for both men.

As part of his preparations for collecting music, Grainger had been in touch with a supplier of recording equipment, P. Holton, who told him on 11 January that his 'Mechanic' (presumably what we would call a technician) would be available whenever Grainger wanted, and that it could be arranged for the machine, together with blank cylinders, to be sent to him the day before he proposed to make recordings. The supplier reported that 'Mr. Ngata', that is, Apirana Ngata, had called in and taken 'those Maori Records' with him to Gisborne. He added that if Grainger visited Gisborne he might be able to hear them and others in Ngata's possession. ${ }^{14}$ What these records were it is now impossible to ascertain, but the reference indicates that Ngata's lifelong interest in the music and songs of his people was already well established. Grainger investigated whether there was a chance of recording Maui Pomare in Wellington on 17 January, offering to operate the equipment himself if the technician from the supplier, 'The Talkeries', was unavailable on a Sunday. ${ }^{15}$ This proved not to be possible due to Pomare's work commitments. ${ }^{16}$

Another contact, Charles C. Reade, possibly of the New Zealand Times, wrote to Grainger in mid-January informing him that he had spoken to Edward Tregear 'in regard to Maori Folk Songs'. Tregear recommended that Grainger visit 'Mr. J. Cowan of the Tourist Department, . . . [and] get in touch with Mr. S. Percy Smith of New Plymouth, where he has the Library of the Polynesian Society'. ${ }^{17}$ Tregear suggested to Reade that Smith would know a number of Maori singers who would be able to sing for him. As recommended, Grainger contacted Smith, who promised to introduce him to a singer in New Plymouth later in the month. ${ }^{18}$ Grainger visited Smith on 26 January and was able to record six cylinders of songs 
in Maori, sung in part by a performer who is recorded on the cylinders and listed in the Grainger Museum catalogue as 'Edwin/Tiemi Te Tupe'. No further information about him has been located. The New Plymouth cylinders include performances by other singers as well, but the catalogues are vague as to their identity. ${ }^{19}$

While there is no record of his reaction to the performances, Grainger comments elsewhere that some recordings he heard were "jolly interesting Maori songs, the $1 / 4$ note intervals being delightfully plain \& striking, but the whole scheme a little flat \& samish artisticly, at first hearing' ${ }^{20}$ His observations on the appeal of the $1 / 4$ note intervals were repeated in a letter to the composer, Frederick Delius, later in the month. ${ }^{21}$ In a letter to his girlfriend, Karen Holten, he speaks of his recording session in New Plymouth and of his concern for the preservation of indigenous music, noting that he had been meeting all kinds of people and trying to impress upon them what he called the 'duty' of preservation, ${ }^{22}$ a theme repeated in letters to other correspondents and one which must have characterised his dealings with many of those whom he met in New Zealand. ${ }^{23}$ His, of course, was not the only voice arguing for preservation, for, as Kay Dreyfus has pointed out, the second annual conference of professional musicians of New Zealand, meeting in Auckland on 25 January, passed a motion 'That steps be taken for the preservation of Maori folksongs' ${ }^{24}$ Grainger's experience and stature as a collector of folk songs must have given great encouragement to those who already held similar beliefs.

But Grainger was no simple romantic, viewing Maori culture in nostalgic terms as the product of a race incapable of adaptation and in terminal decline. On the contrary, he noted, for instance, that the concert he had attended in Rotorua in early February, put on by Maori from Whakarewarewa, had been quite Europeanised and pitched at a tourist audience, but that he had loved it all the same. ${ }^{25}$ Writing to his friend, Balfour Gardiner, that same month, he spoke of 'being hugely taken by the native Maori music', ${ }^{26}$ while he confided to Delius that Maori 'carvings, houses, canoes, weavings, \& tatoo patterns enthrall me greatly'. ${ }^{27}$ Grainger was enthused by virtually all he saw, and he spoke about the culture as having much to offer to people like himself. While he had little understanding of the conditions of work, health or economic standing of the people he was so drawn to, and he was certainly engaged in a kind of appropriation, it was never intended as exploitative. As his clothing in the Laird of Art painting indicates, he translated his admiration for the indigenous culture into his own life, even if it was in an extremely idiosyncratic way.

\section{Cook Islands Music}

It was not Maori music, however, which enthused him the most during his tour of New Zealand. What really took his heart was music from another 


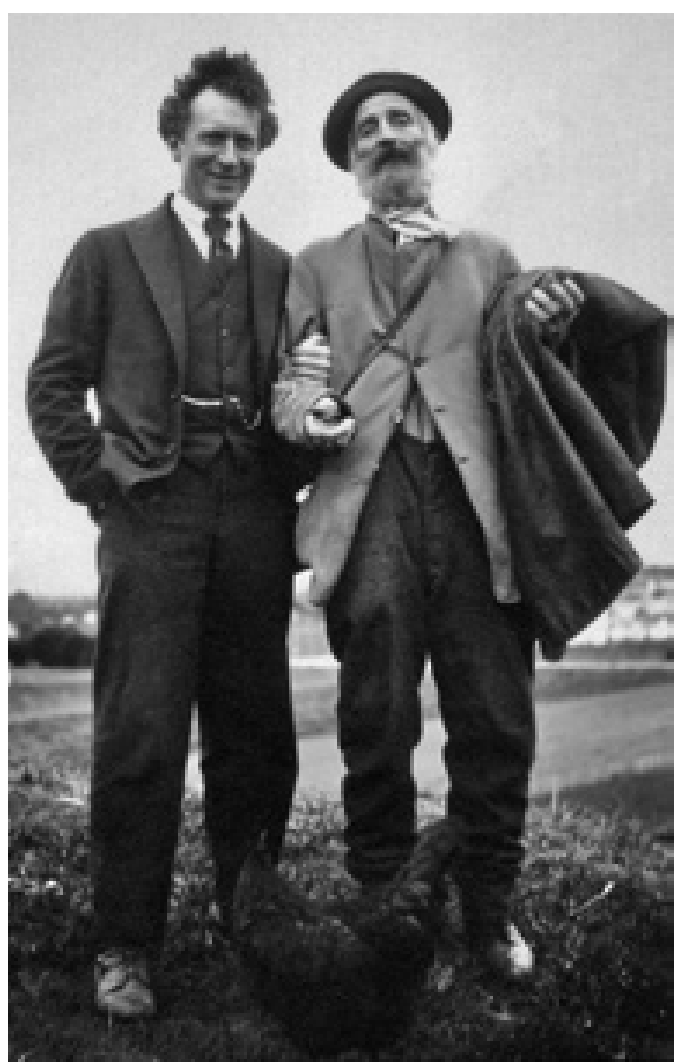

Grainger and Knocks at Otaki, 16 September 1924.

part of Polynesia, from Rarotonga and other islands in the Cook group. How Grainger came to hear this is characteristic of the way he set out systematically to expose himself to as much indigenous culture as he could when he was not fulfilling his own musical engagements.

In Wellington, on the northward leg of the tour, before he had visited New Plymouth, he had heard through a Mrs Elder of Waikanae of a man at Otaki who had many phonograph recordings of Maori music. Grainger arranged to meet him in the Jubilee Hotel, Otaki, on 20 January. The man, Alfred Knocks, a Pakeha who was married to a Maori woman, ${ }^{28}$ brought a few of his recordings to play to Grainger on the hotel's phonograph. These included a number of Maori songs, as well as some sung in January 1907 by a small group of Cook Islanders who had visited Otaki. When presented with gifts by the local Maori, ${ }^{29}$ the songs they sang in thanks had been recorded by Knocks.

The Cook Islanders had come to New Zealand to participate in the Christchurch Exhibition of 1906-07. This exhibition, following the example of the 1904 St Louis Exhibition, included a pa occupied by representatives of the indigenous people of the country, and by those having racial affinities with them and living under one flag. It was intended to provide entertainment and scientific (ethnological) benefits for the exhibition. The pa, 'Arai-te-uru', with its palisade and trenching, covered a three-acre site to the rear of the exhibition building. Various Maori groups occupied the pa in turn, while the other inhabitants included Cook and Niue Islanders and Fijians. The 26 Cook Islanders, from Rarotonga, Mangaia and Aitutaki, 
arrived on 31 October via Auckland..$^{30}$ The official account of the exhibition gives their names, but there are no details of their departure date from the pa or New Zealand. Given they were in Otaki on 12 January 1907, when Knocks apparently recorded them, ${ }^{31}$ it is likely they were on their way back to Auckland and their ship home.

Before accompanying Knocks back to his house to hear more of the recordings made two years previously, Grainger stopped at the railway station to send a telegram to his mother. She had joined the touring party for some of the tour and was then in Wellington. The telegram read, 'never heard the like treat equal to Wagner I am godly lucky love Percy'. ${ }^{32}$ The Cook Islanders' singing had been remarked on by James Cowan, the author of the official account of the Christchurch Exhibition, who praised 'the delightful part-singing harmonies of these South Sea people, so different to the monotonous chant of the Maori', and declared that '[o]nly the people of coral lands can sing as they sang' ${ }^{33}$ Grainger drew attention to the good fortune of Knocks recording the singing: 'No one in Christchurch thought of phonographing these glories; think of it!' ${ }^{34}$ From the hotel, Grainger accompanied Knocks back to his home in Otaki, heard more of his recordings, and was then introduced to his host's family and friends. He loved the house Knocks lived in, its interior 'the most glorious chaos' as he later wrote to his mother. It was characterised by 'stuffy book smells rampant, yearlong grime on hoarded manuscripts, old letters, old interesting documents, all banked feet high on floors, tables, benches. Phonograph records abound on floors, shelves, etc.; carelessly ordered, but neatly labelled. ${ }^{35}$

Grainger was so overcome by what he heard of the Rarotongans' singing that he made copies of the songs at Knocks' home, having obtained a second phonograph in order not to wear out the original cylinders, and then spent most of the night at the house attempting to note down the music from the copies. He remarked in letters that he stayed up till 6 in the morn. The son stayed up for a while \& the father [i.e., Knocks] till 2 o'clock. I slept from 6 to 7 then had breakfast at Jubilee Hotel \& then back to more work before my train left before 10 (am). ${ }^{36}$ Grainger was trying to write down the notes of the songs he heard, managing to do one and part of a second that night. The manuscript survives in the Grainger Museum. ${ }^{37}$ His description in letters of the singing he heard on the wax cylinders gives a vivid sense of the impression it made on him:

One voice sings a certain kind of tune on top, \& another low voice sings a droning kind of tune below, $\&$ in the middle are more purely harmonicly, accompanyingly run parts. The scale is pentatonic in basis, but with often breakings out into solid diatonic (is this originally native, 
or from Europeans?) The whole music is the outpouring of everglad ungloomable souls, merriness incarnate, \& trickling good humor \& devilish energy in overflow. . . If such music isn't the voicing of 'the joy of life', where else shall I look for it? If the best pulses of humanness do not flow in these cannibals we'd be better lacking them. ${ }^{38}$

While the equation of the islanders with cannibals shows the ignorant romanticism inherent in Grainger's sense of them as people, there is no mistaking the seriousness of his attempts to understand their music. ${ }^{39}$

About a month later, the tour itinerary now taking him south again, Grainger was able to make a second visit to Knocks on 20-22 February. Knocks had written to him in the meantime, indicating that he had discovered after Grainger left that the two Rarotongan cylinders he had copied and worked on were themselves copies, not originals. ${ }^{40}$ Knocks said he had located the originals of the Rarotongan music with greater sound volume and clarity of words than the copies. He provided three lines of music with words in Cook Islands Maori and English, part of a song sung by five men and three women on the eve of the islanders' departure from Otaki, the song Grainger had worked on all through that January night. During his second visit, Grainger again worked for very long hours at Knocks' home noting down the music. This time he transcribed another song, sung by four men in thanks for gifts given to them by Otaki Maori. Grainger called this the 'fierce' record and again Knocks later supplied him with the words in the original and translation. ${ }^{41}$ In a radio talk many years later, Grainger gave more details of the circumstances leading to the singing of the song. The Otaki Maori, hearing the names of their shared forefathers mentioned by the Cook Islanders, became so excited

at meeting such long-separated kinsmen [they] took the clothes off their own backs and gave them to the Rarotongans who, coming from a much warmer climate, were lucky enough to possess hardly any. The Rarotongans, not guessing what a torment clothes really are, rose as a man to give ceremonious thanks in song for this wonderful gift. A New Zealand friend of mine, Mr A.J. Knocks of Otaki, a handsome seer-like man full of scientific and artistic intuitions, at once sensed the aesthetic value of this spontaneous outburst of improvised music and got the Rarotongans to sing their songs of thanks into his phonograph. ${ }^{42}$

If the gift of clothes was the inspiration for the singing, it is more likely to have occurred while the Cook Islanders were on their way to the Christchurch Exhibition in the October of 1906, or at the Exhibition, rather than on their way back in January of $1907 .{ }^{43}$ Perhaps Knocks had them repeat the song for his gramophone in January, since the recordings were made at Otaki. 
Before Grainger left Otaki, Knocks generously gave him the originals of his five Rarotongan records and two of his best Maori records. ${ }^{44}$ Reporting the gift to his girlfriend, Grainger noted that he would take the recordings to London and there try to get the Phonograph Company to make what he called 'casts' of them, from which any number of copies could then be produced. It appears that he did get copies made, but in Denmark, and he gave a set of the copied cylinders to Knocks who wrote expressing his gratitude. ${ }^{45}$ Grainger sent another set of the copied cylinders to the Polynesian Society via Percy Smith, who noted that the society would welcome a paper by Grainger 'giving the result of [his] investigations', also commenting that 'possibly there may never be an another [sic] opportunity of securing a like record' ${ }^{46}$ Grainger later arranged for the cylinders to be copied again, this time by the folk-song section of the Library of Congress, who transferred them on to acetate disks. ${ }^{47}$

By the time he left New Zealand in March 1909, Grainger had immersed himself in as much Polynesian culture as he could. He had obtained some recordings of Maori and Cook Island singing, attended concerts, and met a series of important figures, including indigenous performers and people who shared his sense of the importance of preserving Polynesian songs and music. He now counted people such as Sir Peter Buck/Te Rangi Hiroa and Percy Smith, and less well known figures like Alfred Knocks, as firm acquaintances. In addition, he had made preparations to learn Maori, a desire he mentioned to a number of correspondents in early 1909, including Karen Holten. In a later letter he told her that he would soon start on this, having bought a 'large Maori Polynesian comparative dictionary and some other books on these races'. ${ }^{48}$

\section{The Impact of Grainger's Visit}

For Grainger, the visit had an obvious impact on his whole outlook. At the time of his noting down the Rarotongan music he spoke of his desire to have it sung by voices in London, ${ }^{49}$ but whether this ever happened is unknown. He continued to work on the music for at least the following year, since one of the manuscripts of his attempt to note down the singing indicates he was working on this in October-November 1909. ${ }^{50} \mathrm{He}$ must have written to Knocks about his efforts (aided by a friend), since Knocks wrote back asking for a copy of the Rarotongan music Grainger and the unnamed friend were then working on. ${ }^{51}$ This work does not appear to have been ever completed to Grainger's satisfaction; as late as 1955 he wrote to the Turnbull Library, 'I have noted down most of these records, but not as accurately as I intend to . . . When I am satisfied with my notation I will send a copy to your esteemed Library'. ${ }^{52}$ But he often mentioned the Rarotongan music in his writing, describing it in the 1930s as '[r]ushing 
along at breakneck speed [and combining] Bach-like polyphonic complexities with discords that remind us of the most modern European art-music'. ${ }^{53}$ He visited Rarotonga in 1924, noting in a letter to his composer friends that in the evening of the day the steamer was in port the locals played 'accordions, guitars \& ukeleles' but no 'native music' since 'all are attuned to the arrival from the outer world' ${ }^{54} \mathrm{He}$ was told that many of the people who were at the Christchurch Exhibition in 1906 were still alive. Knocks had written to the singers following Grainger's 1909 visit, ${ }^{55}$ but there is no indication in the surviving correspondence with Grainger that he ever had any response. On the same voyage through the Pacific that took Grainger to Rarotonga, the boat stopped in New Zealand and Grainger was able to meet up with Knocks again - much to his surprise, since he had written to Knocks in 1919 but had had no reply. While in Wellington he visited Knocks' house at Otaki for sentimental reasons, finding the old man still alive and spending an hour with him. Knocks was by now in his early seventies, but he entertained Grainger for a fourth time later the same year when the boat again called in at Wellington on its return journey to the United States. ${ }^{56}$

The degree to which Grainger's sense of the need to record and preserve indigenous music, something he urged on all those he met in New Zealand, had an impact is less easy to determine. He certainly saw himself as having sparked a fire, writing to Karen Holten of his expectations of getting 'more than a few good records sent to me in London in the future. I think I have put the small match to a possibly big scientific collection of native musics in these seas. ${ }^{57}$ The precise nature of this collecting project is tantalisingly elusive and the reference could be to any of several proposed undertakings around this time. For instance, one of Grainger's correspondents, C.A. Young of Auckland, wrote later in 1909 of his intention to undertake a collecting trip in 'some of the out-of-the-way Maori country during our coming summer'. He and Knocks, with whom he had been in contact, hoped 'to enlist the service and sympathy of public societies, and possibly Government [would] assist'.$^{58}$ Percy Smith noted in a letter to Grainger in 1910 his hope that someone would obtain recordings of some of the music of the islands besides Rarotonga. ${ }^{59} \mathrm{He}$ mentioned the songs of the Samoans and Hawaiians as being good, also differing from other Polynesian music. Also in 1910, Knocks offered to accompany Grainger on a collecting trip to Rarotonga and in the same letter wrote that he had been told that 'some one in Auckland had promised to get some Rarotongan records for you'. ${ }^{60}$ Grainger wrote from New Zealand to his friend Balfour Gardiner, speaking of his desire to collect in the Pacific: '[m]y dear Balf, the South Seas teem with glorious wayward ecstatic uncollected native musics. Shant we do a trip thro those seas once?' ${ }^{61}$ He never managed it. He does seem, however, to have had 
some impact on at least one prominent figure: Peter Buck/Te Rangi Hiroa, whose superior in the Department of Public Health had recommended him to Grainger as a prominent young Maori whom he should meet. Grainger writing from Auckland on 14 February 1909, mentions that he has 'met such a jolly Maori Dr., Dr. Buck, a great collector of Maori song-words'. ${ }^{62}$ Buck was in the Auckland area in February since he travelled from that city to Kaikohe with the funeral cortège of his predecessor in the seat of Northern Maori, Hone Heke, following Heke's death on 9 February. ${ }^{63}$ Almost certainly the meeting took place in Auckland.

The nature of the discussion when Grainger met Buck is unrecorded. However, a few months later, on 18 May 1909, Buck wrote to his friend Apirana Ngata, urging the need to collect Maori songs, incantations and the like for the production of a university text book. ${ }^{64}$ Ngata, who became a distinguished parliamentarian, eventually published such a book himself, the first two volumes appearing in 1928-29.65 The book contained the words to 200 songs but no music. In the same 1909 letter, Buck continues ' $[\mathrm{t}] \mathrm{hen}$ there is the taking of phonographic records of typical dance music. Percy Grainger has promised to write the music of any records we may send him in the interest of science. He has given me some tips \& is going to write me from London.' He then discusses how the country could be divided up into districts for the collection of a variety of ethnological material. The musicological aspect of this project shows how Grainger was endeavouring to assist those seriously interested in indigenous music. This may have been the project mentioned to Karen Holten, particularly in its scientific approach, which Grainger felt he had helped stimulate.

But the meeting between the two men may have touched on another related topic. It seems highly likely that, so close to his first encounter with the Rarotongan music, Grainger's enthusiasm for what he had heard would come up in his meeting with Buck. If he did mention that group of Polynesian visitors to New Zealand, he may have found that Buck had known them, since he had lived in the pa for the whole period of the Christchurch Exhibition, primarily working as medical officer but also taking part in dances and interpreting for visiting dignitaries. ${ }^{66} \mathrm{~A}$ year after the meeting with Grainger, Buck spent the Parliamentary recess of 1910 in the Cook Islands acting as a medical officer. There is no record of the visit or of the reasons for it, though Buck published three brief articles in 1911 on Cook Island tattoo patterns and canoes. ${ }^{67} \mathrm{He}$ later wrote a number of works on the material culture of the Cooks. It is tempting to speculate that some of the impetus for Buck's 1910 visit to the islands may have arisen from Grainger's enthusiasm for their music, but Buck had joined the Polynesian Society in 1907, was always aware of the close connection between Maori and Cook Island culture, and probably needed no prompting from Grainger. 
Grainger remained interested in Buck after the 1909 meeting. There are a number of books by the latter in Grainger's library, including two on Cook Islands ethnology with Grainger's handwritten note that they were bought at the Bishop Museum, Honolulu, on 20 July $1938 .{ }^{68}$ Buck was Museum Director at the time, and added in Grainger's copies an inscription in Maori, Kia ora koutou katoa, which may mean 'heartiest greeting to you'. That year, 1938, was the year Buck's best-known work, Vikings of the Sunrise, an account for a popular audience of the Polynesian migrations across the Pacific, appeared in the United States. Grainger owned a copy of the first edition of this book, but it carries no inscription. ${ }^{69}$

Equating Polynesians and Vikings made sense in a book pitched at an American market which held the Viking voyages to the New World in high regard. But its origin in Buck's thinking is intriguing, since the concept did not come with the writing of the book. As far back as 1913, when he was a Member of Parliament, he had spoken of New Zealand being discovered by 'the old Polynesian vikings' ${ }^{70}$ Scholars familiar with Buck's work do not appear to have commented in any detail on his seeing his people in this way, and he makes no reference in the book as to how he came to think along these lines. Certainly it was not unusual at the time to see Pacific island peoples as proto-Europeans. In his book on the development of theories about Polynesian origins, Kerry Howe shows how widespread this view was among late nineteenth- and early twentieth-century anthropologists and prehistorians, and how frequently the equation had heroic or romantic overtones. ${ }^{71}$ He notes how Buck's Vikings of the Sunrise demonstrates that his 'basic interpretive, intellectual framework was essentially a product of his Western learning' and teases out the implications of heroic endeavour in the title with its 'images of proud, fearless, highly intelligent and skilled sailors heroically making their way with great purpose over the seas, seeking, finding and colonising new lands before moving onwards again'. ${ }^{72}$ It is at least possible that Buck's specific identification of Polynesians with Vikings may owe something to the meeting with Grainger. The musician's attraction to Old Norse culture is well-covered by his biographers and is the subject of at least one article, ${ }^{73}$ but what is worth noting is how frequently during and after the New Zealand tour in 1909 he referred to Polynesia as 'a new Scandinavia' or 'a 2nd Old-Scandinavia'. ${ }^{4}$ By this Grainger means the Scandinavian culture recorded in Old Norse. For instance, writing to his mother, Rose, at the beginning of the tour, he mentions reading Sir George Grey's book of Maori legends, commenting on their similarity to Icelandic sagas but noting the differences with some disappointment: 'The Maoris seem to fish to get food, \& fight to kill, \& marry to love, \& love to breed, and so on. I cant understand it; they're just as bad as Germans, Continentals, Australians, \& middleclass English. ${ }^{75}$ Nevertheless, his attitude can best 
be summed up in a comment made to Balfour Gardiner not long after his meeting with Peter Buck: 'The South Seas with their lovable graceful fierysouled Viking Islander races may become a 2nd Scandinavia to me. I intend to learn Maori some day. ${ }^{976}$ It is easy to see how such enthusiasm, inflamed by what Grainger found in New Zealand in 1909, might have affected a young man like Buck, who was extremely proud of his Maori heritage.

\section{Acknowledgments}

This paper is based on a lecture given at the Stout Research Centre for New Zealand Studies, Victoria University. I am grateful to the Director of the Centre, Dr Lydia Wevers, for the invitation to speak. The article has benefited from the helpful comments of Dr Allan Thomas. The research work was aided by staff in the Grainger Museum, especially Amelia Peachment who was a source of great assistance, and by staff in the Alexander Turnbull Library. Dr Richard Moyle provided material and information from the Archive of Maori and Pacific Music, University of Auckland, and Ross Somerville of the Dictionary of New Zealand Biography provided me with the reference for the biographical information on Alfred Knocks. The painting Laird of Art and the photograph of Grainger and Knocks are reproduced with the kind permission of Stewart Manville and the Grainger Museum.

1 See Fig.1. The portrait was on loan to the Australian National Portrait Gallery when viewed.

2 In a display label titled 'Towel Clothes' which he prepared for the Grainger Museum, Grainger wrote that his mother had mooted the idea of 'Turkish towels' after they had both been fired by the 'beauty of Maori and South Sea island clothes and fabrics seen in museums in New Zealand and Australia,' Percy Grainger and the Arts of the Pacific: Catalogue, Melbourne, 1979, p.22.

3 Helen Reeves gives a full overview of this aspect of Grainger's life and work in 'A Universalist Outlook: Percy Grainger and the Cultures of Non-Western Societies', in Frank Callaway (comp.), Percy Aldridge Grainger Symposium, 2nd edn, Nedlands, WA, 1997, pp.32-52.

4 The exhibition catalogue (see note 2 above) provides a valuable introduction to Grainger's Pacific interests.

5 For example, John Bird, Percy Grainger, 3rd edn, Sydney, 1998, p.18; Eileen Dorum, Percy Grainger: The Man behind the Music, Hawthorn, Vic., 1986, p.15.

6 When they are mentioned, it is usually only briefly: for example, by Kay Dreyfus in her edition of The Farthest North of Humanness: Letters of Percy Grainger 1901-14, South Melbourne, 1985, p.254. Reeves, op. cit., pp.37 and 39, has provided the most detailed account to date.

7 Bird, op. cit., p.110. The chapter this quotation comes from gives a full account and assessment of Grainger's pioneering activities and radical practice as a collector in 
these years. John Blacking considers Grainger's place in the broader field of world ethnomusicology in his book, 'A Commonsense View of All Music': Reflections on Percy Grainger's Contribution to Ethnomusicology and Music Education, Cambridge, 1987, especially chapters $1-2$.

8 Percy Grainger, 'Collecting with the Phonograph', in Journal of the Folk-Song Society, vol. III/iii no.12, May 1908, pp.147-62; Teresa Balough (comp.), A Musical Genius from Australia: Selected Writings by and about Percy Grainger, 2nd edn, Perth, 1997, pp.19-64.

9 The trademark, based on an 1898 painting by Francis Barraud, Dog Looking at and Listening to a Phonograph, was originally used by the Gramophone Company, later by RCA Victor and EMI. The first version of this painting actually showed the EdisonBell phonograph; later versions and the trademark showed a Gramophone Company machine.

10 Grainger, op. cit., p.19.

11 P.J. Nolan to Marcus Plimmer, Chief of Staff of The Dominion, 12 Oct. 1908. The originals of this and the other two letters mentioned are in the Grainger Museum; photocopies are in the Alexander Turnbull Library, NLNZ, Percy A. Grainger 1882-1961 Papers, 84-194-06. In references to Grainger correspondence, almost all of which is in the Grainger Museum, I indicate which letters have been published and whether photocopies of unpublished letters are located in the Turnbull Library.

12 Grainger to Karen Holten, 3 Jan 1909, W21-212, No.26, Grainger Museum. Whole or parts of his letters to Holten are in Danish; I cite the English translations held by the museum.

13 Grainger to Karen Holten, 5 Jan 1909, letter 236 in The Farthest North of Humanness, p.258.

14 P. Holton to Grainger, 11 Jan 1909; photocopy in the Turnbull Library, Grainger Papers, 84-194-07.

15 Grainger to Rose Grainger, 14 Jan 1909, letter 238 in The Farthest North of Humanness, pp.261-62.

16 James M. Mason to Grainger, 23 Jan 1909; photocopy in the Turnbull Library, Grainger Papers, 84-194-10.

17 Charles Reade to Grainger, 15 Jan 1909; photocopy in the Turnbull Library, Grainger Papers, 84-194-09.

18 Percy Smith to Grainger, 21 Jan 1909; photocopy in the Turnbull Library, Grainger Papers, 84-194-08.

19 [Helen Reeves?, comp.], 'Grainger Museum Sound Archive Catalogue: Phonograph Cylinder Collection-Descriptive Index of Percy Grainger's Historical Wax Cylinder Recordings of English, Danish and Polynesian Folksongs', unpublished ts. [c. 1980?], Grainger Museum; a photocopy of a ms. version of this catalogue is in the Turnbull Library, Percy Grainger, [Catalogue of the] Phonograph Cylinder Collection at the Grainger Museum, Melbourne, 90-107. The names of other performers are given by the cataloguer as 'Ngawaina Hanikamu' and 'Hemapo (of Waitara)'. The catalogue of the Archive of Maori and Pacific Music, Anthropology Department, University of Auckland, which holds copies of these recordings, throws no further light on the performers (catalogue extract supplied to the author by the Director of the Archive, Feb 2002). Copies of the recordings are also held at the Turnbull Library, Collection of Maori and Polynesian Music, LC-0418.

20 Grainger to Rose Grainger, 21 Jan 1909, letter 238 in The Farthest North of Humanness, p.263.

21 Grainger to Frederick Delius, 31 Jan 1909, letter 241 in The Farthest North of Humanness, p.265. 


\section{Percy Grainger and the Early Collecting of Polynesian Music}

22 Grainger to Karen Holten, 1 Feb 1909, W21-219, no.31, Grainger Museum.

23 For example, Grainger to Frederick Delius, 31 Jan 1909, letter 241 in The Farthest North of Humanness, p.265. He returns to the theme in later letter to Karen Holten, 25 Feb 1909, W21-223, no.35, Grainger Museum.

24 The Farthest North of Humanness, p.265, no.9.

25 Grainger to Karen Holten, 4 Feb 1909, W21-220, no.32, Grainger Museum.

26 Grainger to Balfour Gardiner, 16 Feb 1909, letter 242 in The Farthest North of Humanness, p.266.

27 Grainger to Frederick Delius, 31 Jan 1909, letter 241 in The Farthest North of Humanness, p. 265 .

28 Biographical details for Knocks are given in Helen Dempsey and Barbara Swabey, 'The Historic Graves of Rangiatea', Historical Journal (Otaki Historical Society), vol.5, 1982, pp.30-31.

29 Grainger described the circumstances in an essay, 'The Impress of Personality in Unwritten Music', Musical Quarterly, vol.1, 1915, pp.416-35; Teresa Balough, (comp.), A Musical Genius from Australia,. pp.65-79, especially pp.71-72. Also Malcolm Gillies and Bruce Clunies Ross, (eds), Grainger on Music, Oxford, 1999, pp.43-64, especially pp.51-53.

30 James Cowan, Official Record of the New Zealand International Exhibition of Arts and Industries, Held at Christchurch, 1906-07: A Descriptive and Historical Account, Wellington, 1910, pp.353-60. Both Knocks and Grainger consistently refer to the group Knocks recorded as Rarotongans, so the party may have consisted of the 13 people from that island rather than the combined group. I follow Knocks and Grainger in referring to singers in that way, though I have not been able to establish the precise make-up of the group which visited Otaki. However, Knocks does refer to the recordings as being of 'eight Rarotongan singers' in a letter to Grainger, 8 March 1909; photocopy in the Turnbull Library, Grainger Papers, 84-194-02. Cowan has a photo of the Rarotongan group on page 354 .

31 Grainger Museum, Grainger Music Ms. SL1 MG13/6-5: item 1. Grainger's ms. noting of the song he called 'Fierce Rarotonga 1' gives the date of recording as '12.1.07?'. Knocks confirms the date in a sheet accompanying a letter to Grainger, 23 Jan 1909; photocopy in the Turnbull Library, Grainger Papers, 84-194-02.

32 Grainger to Rose Grainger, 20 Jan 1909, letter 239 in The Farthest North of Humanness, p.263.

33 Cowan, op. cit., p.353.

34 Grainger to Rose Grainger, 21 Jan 1909, letter 240 in The Farthest North of Humanness, p.264.

35 Ibid.

36 Ibid.; a similar account of his labour is in a letter to Karen Holten, 16 \& 21 Jan 1909, W21-217, no.29, Grainger Museum.

37 Grainger Museum, Grainger Music Ms. SL1 MG13/6-4: item 5.

38 Grainger to Rose Grainger, 21 Jan 1909, letter 240 in The Farthest North of Humanness, p.265.

39 He later described the singing style as "the kind of polyphonic music called "himines" in Tahiti' in a letter to the Turnbull Library Acquisitions Officer, 12 April 1955; photocopy in the Turnbull Library, Grainger Papers, 84-194, preliminary list. For a thorough account of this style of singing in Tahiti and the southern Cook Islands, see Mervyn McLean, Weavers of Song: Polynesian Music and Dance, Auckland, 1999, pp.33-46 and 75-84.

40 Knocks to Grainger, 23 Jan 1909; photocopy in the Turnbull Library, Grainger Papers, 84-194-02. 


\section{Journal of New Zealand Studies}

41 Knocks to Grainger, 8 March 1909; photocopy in the Turnbull Library, Grainger Papers, 84-194-02.

42 Percy Grainger, 'Can Music be Debunked?' broadcast on WEVD (New York), 27 June 1933; Gillies and Clunies Ross, (eds), Grainger on Music, p.268.

43 James Cowan noted their discomfort in cold Christchurch weather: 'They were exotics, plainly, as one saw when sharp winds blew, for then they shivered like tropic birds blown astray on to bleak southern shores' (op. cit., p.353). The photos illustrating Cowan's account show some of the islanders wearing warm European clothing.

44 Grainger to Karen Holten, 25 Feb 1909, W21-223, no.35, Grainger Museum.

45 Knocks to Grainger, 8 Feb 1910; photocopy in the Turnbull Library, Grainger Papers, 84-194-02.

46 Smith to Grainger, 22 July and 31 Oct 1910, Grainger Museum; photocopies in the Turnbull Library, Grainger Papers, 84-194-08.

47 The wax cylinders of Knocks' original recordings of the Cook Islands singers, the working copies Grainger used (up to four of some cylinders) and a set of the Dansk Phonograph Magazin copies are in the Grainger Museum, Box nos. 19, P1-P14; 20, not separately numbered; $21,1-5 ; 22$, not separately numbered. The museum also holds a set of the acetate disk copies and a set of 1/4 inch analogue tape copies. Chris Long, Performing Arts Museum, Melbourne, who electronically remastered the tape from the cylinders in 1984, notes on the box that the quality of the original Knocks recordings is poor. The copies in the Turnbull Library, Collection of Maori and Polynesian Music, MT10-0011 and LC-0418 (listening copy), derive from the Library of Congress disks (Grainger to Mr Park, Turnbull Library Acquisitions Officer, 12 April 1955; photocopy in the Turnbull Library, Grainger Papers, 84-194, preliminary list). The copies in the Archive of Maori and Pacific Music, University of Auckland, were obtained from the Grainger Museum and appear to derive from the 1984 remastered tape (tracks C87/027.711 are of the Knocks original recordings).

48 Grainger to Karen Holten, 14 Jan 1909 and 25 Feb 1909; Grainger Museum, W21-216, no.28 and W21-223, no.35. The dictionary was Edward Tregear's The Maori-Polynesian Comparative Dictionary, Christchurch, 1891, which is still in his library. One of the other books was Percy Smith's Hawaiki: The Original Home of the Maori with a Sketch of Polynesian History, 2nd edn, Christchurch, 1904. His copy is inscribed 'Wellington. N.Z. Feb 09'. His purchase may also have included his copies of Tregear's Fairy Tales and Folk-Lore of New Zealand and the South Seas, Wellington, 1891, and Apirana Ngata's Complete Manual of Maori Grammar and Conversation with Vocabulary, rev ed, Christchurch, 1901. His library indicates he was still obtaining books on Maori language in the 1930s.

49 Grainger to Frederick Delius, 31 Jan 1909, letter 241 in The Farthest North of Humanness, p. 265 .

50 Grainger Museum, Grainger Music Ms. SL1 MG13/6-5: item 2.

51 Knocks to Grainger, 8 Feb 1910; photocopy in the Turnbull Library, Grainger Papers, 84-194-02.

52 Grainger to Mr Park, Turnbull Library Acquisitions Officer, 12 April 1955; photocopy in the Turnbull Library, Grainger Papers, 84-194.

53 Grainger, Music: A Commonsense View of All Types, Sydney?, 1934, p.11; 'A Commonsense View of All Music', in Blacking, op. cit., p.157.

54 Round Letter ('Percy at Tahiti, Rarotonga \& New Zealand, May-June 1924'); letter 19 in Malcolm Gillies and David Pear, (eds), The All-Round Man: Selected Letters of Percy Grainger 1914-1961, Oxford, 1994, p.72.

55 Knocks to Grainger, 8 March 1909; photocopy in the Turnbull Library, Grainger Papers, 84-194-02. 


\section{Percy Grainger and the Early Collecting of Polynesian Music}

56 Several photos survive from this visit, including one of Grainger and Knocks together (Grainger Museum W4-62). See Fig.2.

57 Grainger to Karen Holten, 25 Feb 1909, W21-223, no.35, Grainger Museum.

58 Young to Grainger, 16 Aug 1609; photocopy in the Turnbull Library, Grainger Papers, 84-194-11. In a previous letter, 7 Feb 1909, Young thanks Grainger for the loan of the Journal of the Folk-Song Society, presumably the issue containing Grainger's article on collecting with the phonograph.

59 Smith to Grainger, 22 Feb 1910; photocopy in the Turnbull Library, Grainger Papers, 84-194-08.

60 Knocks to Grainger, 8 Feb 1910; photocopy in the Turnbull Library, Grainger Papers, 84-194-02.

61 Grainger to Balfour Gardiner, 16 Feb 1909, letter 242 in The Farthest North of Humanness, p.266.

62 Grainger to Karen Holten, 14 Feb 1909, W21-221, no.33, Grainger Museum.

63 J.B. Condliffe, Te Rangi Hiroa: The Life of Sir Peter Buck, Christchurch, 1971, p.93 and p.110.

64 Buck to Apirana Ngata, 18 May 1909, National Archives of NZ, MA 31/42.

65 A.T. Ngata, collector, Nga Moteatea: He Maramara Rere No Nga Waka Maha, 2 parts, Hastings, 1928-29.

66 Cowan, op. cit., pp.321-22.

67 See further M.P.K. Sorrenson (ed), Na To Hoa Aroha From Your Dear Friend: The Correspondence between Sir Apirana Ngata and Sir Peter Buck 1925-50, 3 vols., Auckland, 1986-88, vol.1, p.27 and no.65.

68 Te Rangi Hiroa (Peter H. Buck), Ethnology of Tongareva, Bernice P. Bishop Museum Bulletin no.92, Honolulu, 1932; Ethnology of Manihiki and Rakahanga, Bernice P. Bishop Museum Bulletin no.99, Honolulu, 1932. Grainger's library is in the Grainger Museum and is catalogued within the University of Melbourne Library collection.

69 Peter H. Buck (Te Rangi Hiroa), Vikings of the Sunrise, New York, 1938. Grainger's copy is in the Grainger Museum.

70 New Zealand Parliamentary Debates, vol.167 covering 17 Nov. to 15 Dec. 1913, 1913, p.413.

71 Kerry R. Howe, The Quest for Origins: Who First Discovered and Settled New Zealand and the Pacific Islands?, Auckland, 2003. Bronislaw Malinowski had equated Melanesians with Greek Argonauts in the title of his Argonauts of the Western Pacific: An Account of Native Enterprise and Adventure in the Archipelagoes of Melanesian New Guinea, London, 1932.

72 Ibid., pp.172 and 194.

73 Margaret Birtley, 'Percy Grainger and his Study of Icelandic', Frá suthlagri strönd (From a Southern Shore), no.1, 1985, pp.24-29. Grainger saw Old Norse culture very much in the same romantic, heroic light which informs Buck's use of the term 'Vikings' in his book title.

74 Grainger to Karen Holten, 18 Feb 1909, letter 243 in The Farthest North of Humanness, p.267; Grainger to Herman Sandby, 11 Aug. 1909, letter 271 in The Farthest North of Humanness, p.307.

75 Grainger to Rose Grainger, 1 Jan 1909, letter 235 in The Farthest North of Humanness, p.257.

76 Grainger to Balfour Gardiner, 16 Feb 1909, letter 242 in The Farthest North of Humanness, p.266. 